\title{
Hoping for a better future
}

\author{
Ildefonso Rodríguez-Leyva* \\ Department of Neurology, Faculty of Medicine, Hospital Central Dr. Ignacio Morones Prieto, Universidad Autónoma de San Luis Potosí, SLP, Mexico
}

\section{Dear all,}

We are culminating another year, and with it, the hopes and fears that we had at the beginning of it have been presented; some happened for the better, others became cruel realities that we have to face. One great hope was that the coronavirus-19 would finally be eradicated and that consequently the population would return to normality: students to their classrooms, workers to their jobs, professionals to their daily development, hoping that economic activity would increase leading to generating wealth and welfare in the population.

However, worldwide vaccination has not been enough. Even though most of the population has responsibly taken instructions at a central level, the problem prevails in our country. We are still unable to normalize our academic, labor, and professional activities, and the economy continues to suffer alterations that have led to devaluation and inflation.

It seems illogical that we want to solve serious issues, when we have allowed them to progress to the point of making regrettable decisions. We have just approved abortion when it would seem more critical and healthier to educate young people on sexuality, self-respect, and the importance of responsibility when having sex. We shorten the school plans in the university curriculum trying to promote efficiency, but by forming less prepared professionals with fewer resources to generate social welfare. Despite knowing the importance of primary prevention to optimize health, we continue to settle for secondary prevention, which in most cases is too late to help our patients.
It is the end of another year in the life of this publication. I want to thank those who read and follow this journal on behalf of all of us who make its bimonthly publication possible, even in adversity. I am incredibly grateful to the readers, who consider it a tool to continue updating their knowledge in neurosciences; to the peer reviewers who, with their efforts, make the authors improve their articles and enrich each paper with their criticisms and comments. And to the authors, who have trusted this journal to share their experiences within the medical and scientific community and who broaden the knowledge and help many patients indirectly.

I would also like to extend my gratitude for the exceptional work of Dr. Maria Ahn and the editorial team at Publicaciones Permanyer, who oversee the production of each publication from the reception of the papers, peer-review compliance, the design of galleys, and the responses to each query generated in all papers before they get published.

We end another year with the greatest hope that in 2022 we can finally hold face-to-face gatherings, meet with friends, spend more time with our families, and generate wealth in a country that needs education, health, security, and general welfare.

I wish you all a happy end of 2021, and may the year be one filled with health, success, joy, and love.

Happy 2022!

Sincerely yours, Ildefonso Rodriguez Leyva
*Correspondence:

Ildefonso Rodríguez-Leyva*

E-mail: ilrole@yahoo.com.mx
Available online: $15-11-2021$

Date of reception: 20-10-2021

Date of acceptance: 25-10-2021

DOI: 10.24875/RMN.M21000084
Rev Mex Neuroci. 2021;22(6):218-218

www.revmexneurociencia.com

2604-6180/ @ 2021 Academia Mexicana de Neurología A.C. Published by Permanyer. This is an open access article under the CC BY-NC-ND license (http://creativecommons.org/licenses/by-nc-nd/4.0/). 